\title{
Existe aumento da vontade na mania, na hipomania e na impulsividade em geral?
}

\author{
Is there hightened will in mania, hypomania and in impulsivity in general?
}

Márcio Amaral ${ }^{1}$

\section{Senhor Editor,}

Sempre que os livros de referência para qualquer forma de saber fazem afirmações diametralmente opostas em relação a algum tema central, podemos afirmar que estamos diante de um grave problema conceitual. É o que se passa com a caracterização da situação da vontade nos pacientes em mania, hipomania ou no transtorno de personalidade borderline. Se, por um lado, estudiosos como Karl Jaspers ${ }^{1}$ e Nobre de Mello ${ }^{2}$ concluem estar a vontade gravemente diminuída nessas situações, autores norte-americanos como Yager e Gitlin ${ }^{3}$ afirmam exatamente o oposto. Para esses últimos, a vontade patologicamente aumentada, observada primariamente em estados maníacos, é caracterizada por desejos excessivamente intensos e uma grande capacidade de tomar decisões, com questões complexas sendo deliberadas em apenas um "instante".

Estamos convencidos de que esse aparente impasse conceitual teve sua origem na omissão, por parte dos norte-americanos, da distinção necessária entre desejo e vontade. Quem primeiro estabeleceu a importante diferença entre ambos foi Kant ${ }^{4}$, para quem a vontade seria "... uma faculdade bem diferente do simples desejar; a saber (...) a faculdade de se determinar a agir com inteligência, segundo as leis da razão, independentemente dos instintos naturais".

Dessa forma, o desejar seria apenas o primeiro momento da função da vontade ${ }^{5-6}$, a qual teria um importante papel frenador em relação ao desejo inicial, além de Ihe atribuir uma projeção para o futuro. É esse, aliás, o significado que a linguagem popular atribui à expressão "ter força de vontade", uma vez que é sempre aplicada no sentido de uma espécie de vitória contra um impulso ou desejo inicial, seja em relação ao uso de substâncias, ao comer demais, ao sedentarismo e assim por diante. Quando no trecho do mais importante tratado da psiquiatria moderna Yager e Gitlin³ se referem à "capacidade de tomar decisões dos maníacos", deviam, em verdade, inverter completamente seu raciocínio, pois o que é evidente, nesses casos, é a incapacidade dos pacientes em mania de adiar essas decisões e melhor avaliar as situações, quase sempre com consequências desastrosas.

Não é novidade para ninguém a aversão que o pragmatismo norte-americano desenvolveu para com toda filosofia um pouco mais especulativa. Em muitas áreas, isso representou um ganho considerável. No que se refere ao funcionamento da mente humana, entretanto, gerou insuficiências gritantes. Efetivamente, parece não haver muito espaço entre a nova geração para as ricas lucubrações de Karl Jaspers ${ }^{1}$ e Nobre de Mello². Havia

1 Professor adjunto do Instituto de Psiquiatria da Universidade Federal do Rio de Janeiro (IPq-UFRJ).

Recebido em 25/11/2009 Aprovado em 26/11/2009
Endereço para correspondência: Márcio Amaral

Av. Venceslau Brás, 71 fundos - Botafogo - 22290-140 - Rio de Janeiro, RJ

Telefone: (21) 3873-5506

E-mail:marcioamaral.ipub@uol.com.br 
mesmo a necessidade de se objetivar o conhecimento, mas os norte-americanos agiram como a ama desastrada que, depois de lavar o bebê, atirou-o fora junto com a água utilizada. De qualquer maneira, e um pouco mais adiante no mesmo capítulo, Yager e Gitlin quase chegaram ao proposto pelos eminentes psicopatólogos quando afirmaram que os pacientes maníacos "... compartilham muitos aspectos com aqueles indivíduos que apresentam diminuição da vontade, na medida em que os desejos intensos e decisões rápidas frequentemente refletem impulsividade (...) uma fuga da verdadeira vontade e da tomada de decisão ${ }^{\prime \prime}$. Quem sabe se, na próxima edição daquele tratado norteamericano, eles não resolverão, por fim, esse dilema quase "hamletiano"?

\section{REFERÊNCIAS}

1. Jaspers K. Psicopatologia general. Buenos Aires: Editorial Beta; 1963.

2. Nobre de Mello AL. Psiquiatria. Rio de Janeiro: Civilização Brasileira; 1979.

3. Yager J, Gitlin MJ. Clinical manifestations of psychiatric disorders. In: Kaplan HI, Sadock BJ, editors. Comprehensive Text Book of Psychiatry. Baltimore: Williams and Wilkins; 2005, p. 964-1002.

4. Kant I. Fundamentação da metafísica dos costumes. São Paulo: Abril SA Cultural e Industrial; 1974.

5. Amaral M, Fontenelle L. Controvérsias acerca da vontade. J Bras Psiquiatr. 2001;50:43-9.

6. Amaral M. Psicopatologia e semiologia básicas. Niterói: Editora da Universidade Federal Fluminense; 2004. 